\title{
Problematic Facebook use behavior and locus of control in physiotherapy students
}

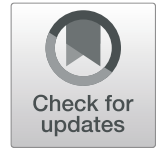

\author{
Yesim Salik Sengul ${ }^{1} \mathbb{D}$, Turhan Kahraman ${ }^{2}$ (D) and Buse Ozcan Kahraman ${ }^{1 *}$ (D)
}

\begin{abstract}
Background: Problematic Facebook use is a broader umbrella for term addictive-like symptoms, and scarce selfregulation related to Facebook use reflecting social and personal problems, and many studies have suggested that it is associated with many psychosocial problems. Locus of control (LOC) is described as a personality trait developed through social learning theory. Recently, LOC has got attention from both the patient's and clinician's perspectives. In addition, higher external LOC is associated with problematic Internet use. The aim was to investigate whether problematic Facebook use is associated with LOC. Four hundred twenty-one university students were enrolled in this cross-sectional study. Problematic Facebook use was determined by the Bergen Facebook Addiction Scale, and the participants were divided into two groups as neutral users and problematic users. Locus of control was assessed using the Locus of Control Scale, including subscales of personal control, belief in chance, the meaninglessness of the effortfulness, belief in fate, and belief in an unjust world.

Results: In total, 333 students were eligible for the study. There were 66 students with neutral Facebook use (19.8\%), and the remaining ( $n=267)$ had problematic Facebook use (80.2\%). No significant difference was observed in the demographic characteristic of neutral and problematic Facebook users ( $p>0.05)$. Problematic Facebook users had significantly higher scores on the meaninglessness of the effortfulness ( $p<0.001)$, belief in fate $(p=0.019)$, and belief in an unjust world ( $p=0.004)$ compared to the neutral Facebook users.

Conclusions: The results showed that the physiotherapy students having a problematic Facebook had significantly higher scores on the meaninglessness of the effortfulness, belief in fate, and belief in an unjust world compared to neutral Facebook users. All these negative thoughts might be a problem both for students themselves and their future patients.
\end{abstract}

Keywords: Facebook, Internet, Addiction, Student, Physiotherapy

\section{Background}

Problematic Facebook use is a broader umbrella term for addictive-like symptoms, and scarce self-regulation related to Facebook use reflecting in social and personal problems, and many studies have suggested that it is associated with many psychosocial problems [1]. The outbreak of COVID-19 has significantly restricted people's everyday life and contributed to enhanced social media use [2], and people, especially students, have started to

\footnotetext{
* Correspondence: buse.ozcan@deu.edu.tr

${ }^{1}$ School of Physical Therapy and Rehabilitation, Dokuz Eylül University, Izmir, Turkey

Full list of author information is available at the end of the article
}

use social media since they are at home and hostels and have more free time more than before. During the COVID-19, our personal and professional lives interfered (mixed) through Facebook, Twitter, and Instagram [3]. Also, a study showed that $50.8 \%$ of the university students reported usually obtaining their information about COVID-19 from social media such as Facebook, Twitter, and Instagram [4]. It was shown that $47.8 \%$ of students reported they were watching new stories about COVID-19 for $1-3 \mathrm{~h}$ a day and $4.8 \%$ for more than $6 \mathrm{~h}$ [4]. In addition, education in universities in Turkey and many countries have currently begun digital instruction and distance learning [5]. In addition to get information 
about the latest news and leisure time engagements, many university students use social media networks as an instrument to disseminate information and to communicate in their academic and research activities [6]. Overall, many external factors of life can influence Facebook and social media use.

Locus of control (LOC), connected to individuals' characteristics, is described as a personality trait developed through social learning, and it has two main categories as internal and external LOC [7]. Internal LOC is an indicator of individual actions and initiatives, while luck, fate, and other persons affect external LOC. Some studies have indicated that individuals who have external LOC spend more time on academic activities for the same job than individuals with internal LOC, and also, these persons have better results at school and competitions $[8,9]$. This situation is associated with personality traits as low self-esteem, depressive mood, feeling of loneliness, and passive personality structure [8].

A study conducted on 1245 college students in China showed that excessive use of a mobile phone-based messaging and social networking application is associated with external LOC [10]. Thus, people who believe that external factors cause events in their lives tend to overuse this application. Externals perceive less control of their environment and hence fail to regulate their social networking application and behavior [10]. Another Chinese study also revealed that more lonely, unhappy, and externally controlled students were more likely to be engaged in online social interaction [11].

A person's control beliefs over many fields of life are an important determinant. Health LOC, another version of LOC, was developed to evaluate the patient's belief in the health and physiotherapy field [12-15]. Turkish patients had a high chance and external beliefs, and these factors were related to increased disability levels, decreased quality of life, and increased pain severity [14, 15]. Most physiotherapy professionals deal with patients with chronic pain for many treatment sessions. Chronic pain has a complex mechanism, leading to impairments in patients' lives as a biopsychosocial being. In the literature, chronic pain has been reported to cause chronic pain behavior, depression, fear of activity, and anxiety [16]. Patients with chronic pain need more external support, especially from health practitioners like life coaches [13]. The biopsychosocial model should be adapted to clinical practice since recent evidence suggests that psychosocial risk factors lead to prolonged disability and increased pain levels [17]. Patients with a developing longterm disability risk and higher levels of catastrophizing or depression might have shown more significant reductions in disability if physiotherapists' attitudes and beliefs changed [18]. The importance of behavior and positive belief of physiotherapists in managing patients with chronic pain is well known [19]. Therefore, investigating the association between problematic Facebook use and a person's control beliefs in physiotherapist candidates emerges as an important topic. The present study aimed to investigate the association between problematic Facebook use and LOC.

\section{Methods \\ Participants}

This cross-sectional study sample consisted of 421 students from School of Physical Therapy and Rehabilitation, Dokuz Eylül University, Izmir, Turkey. All the volunteer students from all the classes were included in the study. Non-Facebook users and students with missing data in their questionnaires were excluded. The researchers explained the study to the students in a course, and the questionnaires were distributed. The students were asked not to exchange ideas with each other while filling out the questionnaires.

The study protocol was approved by the Noninvasive Research Ethics Board of Dokuz Eylül University (registration number: 2757-GOA), and all participants gave informed consent for the use of their data in the study. The required sample size was calculated as 194 with type I error rate $=0.05$, type II error rate $=0.20$, and expected correlation coefficient $=0.20$ as a study reported that the correlation coefficients between LOC and internet addiction were ranged from -0.13 to 0.27 among students [20].

\section{Study outcome measures}

A simple data collection form was prepared to gather demographic characteristics and Facebook use time. This form had questions asking participant's gender, age, year of study, and Facebook use time (hours/day). After filling out this form, the participants filled out the Locus of Control Scale and Bergen Facebook Addiction Scale.

\section{Locus of Control Scale}

The Locus of Control Scale is a valid and reliable LOC measure with a more comprehensive and simple factor structure than the previous Turkish version of Rotter's Internal-External Scale for the Turkish population [21]. The scale consists of 47 items answered in a 5-point Likert-type scale with that increasing scores indicate external control [21]. The LOC scale is divided into five subscales: personal control, belief in chance, the meaninglessness of the effortfulness, belief in fate, and belief in an unjust world. The LOC scale had a high internal consistency (ICC=0.92), and five domains explained $50.63 \%$ of the variance [21]. 


\section{Bergen Facebook Addiction Scale}

The Bergen Facebook Addiction Scale (BFAS) is a valid and reliable instrument for measuring Facebook addiction [22]. It comprised 18 items, three for each of the six core features of addiction: salience, mood modification, tolerance, withdrawal, conflict, and relapse. Each item was scored on a 5-point Likert-type scale where higher scores indicating greater Facebook addiction [22]. The internal consistency of the scale is 0.83 , and a 3 -week test-retest reliability is 0.82 [22]. This scale was translated into Turkish, and this adapted version was shown to be valid and reliable [23]. The Turkish version of BFAS had high internal consistency ( $\mathrm{ICC}=0.93$ ), and the model fit indices of the confirmatory factor analysis applied to determine the construct validity of the scale were adequate [23]. The cutoff points of BFAS were accepted as 20 , and the participants were divided into two groups as neutral Facebook use and problematic Facebook use. Further, the problematic Facebook use was categorized as mild (21-40), moderate (41-69), and severe Facebook addiction (70-90).

\section{Statistical analysis}

Data were analyzed using the IBM SPSS for Windows software (Version 25.0. Armonk, NY: IBM Corp.) The normal distribution of data was investigated using visual and analytical methods (Kolmogorov-Smirnov test) to determine. Due to the non-normal distribution of age, LOC subscales, and BFAS, non-parametric statistics were conducted. Descriptive analyses were presented as median values and interquartile range (IQR) for continuous variables and number and percent for nominal variables. Comparison between the students having neutral and problematic Facebook use was conducted using the Mann-Whitney $U$ test. In addition, a logistic regression analysis was used to analyze the predictors of problematic Facebook use. The level of statistical significance was set at $p<0.05$.

\section{Results}

Ninety-one students were excluded from the study because of no Facebook use $(n=43)$ and incomplete data $(n=48)$. Therefore, 333 students' data were analyzed. The sample consisted of 164 males (49.2\%) and 169 females $(50.8 \%) ;$ median age $=22(\mathrm{IQR}=21-23)$ years. There were 66 students with neutral Facebook use (19.8\%), and the remaining $(\mathrm{n}=267)$ had problematic Facebook use (80.2\%). There were 161 (48.3\%) students with mild Facebook addiction, 99 (29.7\%) with moderate, and 7 (2.1\%) with severe Facebook addiction. No significant difference was observed in the basic sociodemographic characteristic of neutral and problematic Facebook users $(\mathrm{p}>0.05)$. Median Facebook time was significantly higher in the problematic Facebook users $(\mathrm{p}<0.001)$ (Table 1).

Problematic Facebook users had significantly higher scores on the meaninglessness of the effortfulness $(\mathrm{p}<$ $0.001)$, belief in fate $(\mathrm{p}=0.019)$, and belief in an unjust world $(\mathrm{p}=0.004)$ compared to the neutral Facebook users (Table 2). Logistic regression analysis revealed that meaninglessness of the effortfulness was the only significant predictor of the problematic Facebook use with an odds ratio of 1.12. Figure 1 presents comparisons of the locus of control domains between neutral vs. problematic Facebook users.

The BFAS scores significantly correlated with personal control (rho $=0.16, p=0.008)$, meaninglessness of the effortfulness ( $r h o=0.31, p<0.001$ ), and belief in an unjust world (rho=0.20, $\mathrm{p}=0.001$ ) (Table 3). However, no significant correlation was observed between the BFAS and belief in chance and belief in fate (p>0.05) (Table 3).

Table 1 Characteristics of the participants

\begin{tabular}{|c|c|c|c|c|}
\hline & Total sample $(n=333)$ & Neutral Facebook users $(n=66)$ & Problematic Facebook users $(n=267)$ & $\mathbf{p}$ \\
\hline \multicolumn{5}{|l|}{ Gender } \\
\hline Female & $169(50.8)$ & $36(54.5)$ & $133(49.8)$ & \multirow[t]{2}{*}{0.496} \\
\hline Male & $164(49.2)$ & $30(45.5)$ & $134(50.2)$ & \\
\hline Age (years), median (IQR) & $22(21-23)$ & $22(20-23)$ & $22(21-23)$ & 0.093 \\
\hline \multicolumn{5}{|l|}{ Year of study } \\
\hline 1st (Freshmen) & $47(14.1)$ & $13(19.7)$ & $34(12.7)$ & \multirow[t]{4}{*}{0.490} \\
\hline 2nd (Sophomores) & $71(21.3)$ & $12(18.2)$ & $59(22.1)$ & \\
\hline 3rd (Juniors) & $120(36.0)$ & $24(36.4)$ & $96(36.0)$ & \\
\hline 4th (Seniors) & $95(28.5)$ & $17(25.8)$ & $78(29.2)$ & \\
\hline Facebook use time (hours/day) & $1(0.5-1)$ & $0.5(0.25-1)$ & $1(0.5-2)$ & $<0.001^{*}$ \\
\hline BFAS & $33(22-45)$ & $18(18-19)$ & $37(28-49)$ & $<0.001^{*}$ \\
\hline
\end{tabular}

* $\mathrm{p}<0.05$

Data values are number (percent) unless otherwise stated

$B F A S$, Bergen Facebook Addiction Scale; IQR, interquartile range 
Table 2 Comparison of the locus of control domains between neutral vs. problematic Facebook users

\begin{tabular}{|c|c|c|c|c|c|c|}
\hline Locus of control domains & $\begin{array}{l}\text { Total sample }(n= \\
\text { 333) }\end{array}$ & $\begin{array}{l}\text { Neutral Facebook users } \\
(n=66)\end{array}$ & $\begin{array}{l}\text { Problematic Facebook users } \\
(n=267)\end{array}$ & $\mathrm{p}$ & OR & $95 \% \mathrm{Cl}$ \\
\hline Personal control & $50(43-56)$ & $50(43-55)$ & $50(43-56)$ & 0.941 & 1.0 & $\begin{array}{l}0.97 \text { to } \\
1.03\end{array}$ \\
\hline Belief in chance & $32(28-35)$ & $32(27.5-35.5)$ & $32(29-35)$ & 0.452 & 0.97 & $\begin{array}{l}0.91 \text { to } \\
1.04\end{array}$ \\
\hline $\begin{array}{l}\text { Meaninglessness of the } \\
\text { effortfulness }\end{array}$ & $23(19-26)$ & $20(17-23.25)$ & $24(20-27)$ & $\begin{array}{l}< \\
0.001^{*}\end{array}$ & $1.12^{*}$ & $\begin{array}{l}1.03 \text { to } \\
1.20\end{array}$ \\
\hline Belief in fate & $9(8-11)$ & $8(6-10.5)$ & $9(9-11)$ & $0.019^{*}$ & 1.08 & $\begin{array}{l}0.97 \text { to } \\
1.21\end{array}$ \\
\hline Belief in an unjust world & $12(9-14)$ & $11(8-12.25)$ & $12(10-15)$ & $0.004^{*}$ & 1.05 & $\begin{array}{l}0.95 \text { to } \\
1.17\end{array}$ \\
\hline
\end{tabular}

*p $<0.05$

Data values are median (interquartile range)

$O R$, odds ratio; $C l$, confidence interval

\section{Discussion}

In the present study, the association between problematic Facebook use and LOC has been investigated. The results showed that the problematic Facebook users had significantly higher scores on the meaninglessness of the effortfulness, belief in fate, and belief in an unjust world compared to the neutral Facebook users. Besides, increased Facebook addictive behavior was significantly associated with increased external control in personal control, meaninglessness of the effortfulness, and belief in an unjust world. Among the investigated variables, the meaninglessness of the effortfulness was the only significant predictor of problematic Facebook use.

Facebook use is an important indicator and a specific form of Internet addiction. The Internet and Facebook addiction level have been high, especially among students in health-related studies [24-26]. Studies on various undergraduate health students showed that the physiotherapy group had higher Internet addiction [26, 27]. Among the present study participants, most of the students had a mild and moderate level of Facebook addictive behavior determined by the BFAS.

The findings of the current study indicated that the problematic Facebook users believe that if something happens, it will happen, in other words, meaninglessness to try. In addition, they believe fate has a significant role in human life, and powerful people determine the direction of human life. All these negative thoughts might be a problem both for the students themselves and their future patients.

Self-control is crucial for addictive behavior and connected with self-esteem and managing stress. Firat [28] found a negative relationship between Facebook addiction and self-control. Consequently, as indicated in most of the studies above, Internet addiction, including Facebook, leads to impaired inhibitory control processing, decreased social interactions, and depression [29]. Researchers have indicated the importance of perceived control in managing stress and academic achievement $[9,30]$. LOC was defined as individuals' attributions for the causes of outcomes [7]. If the behavior is viewed as determined by one's influence, the LOC is labeled internal. Individuals with a high internal LOC are better psychologically adjusted than those having higher external LOC [10]. On the contrary, if the expectancy for the behavior is perceived as being outside one's control, it is considered external LOC, highlighting individuals' point of view for external factors such as fate, luck, or powerful others to be responsible for an outcome [10]. Internal LOC was related to academic success, self-esteem, and stress management [31, 32]. Internet addiction was negatively associated with internal LOC [20].

Similarly, Iskender et al. [33] found that Internet addiction was associated with less social self-efficacy and internal academic LOS and high external academic LOS. The present study results are consistent with the finding that fate beliefs like meaninglessness of the effortless, belief in fate, and belief in an unjust world in the LOC scale were associated with Facebook problematic use. Another study also reported that more lonely and unhappy students with high external LOC were more likely to be engaged in online social interaction [11]. These findings have supported that problematic Facebook use is associated with external factors such as chance and fate beliefs.

Patients' benefits from the therapy might be related to the physiotherapists' attitudes and beliefs [18]. Also, the importance of behavior and positive belief of physiotherapists in managing patients with chronic pain is well known [19]. The current study is important by providing information about the association between problematic Facebook use and a person's control beliefs in physiotherapist candidates. Since our study has a crosssectional design, we cannot show a cause-effect relationship between the problematic Facebook use and LOC. However, reducing problematic Facebook use may help 


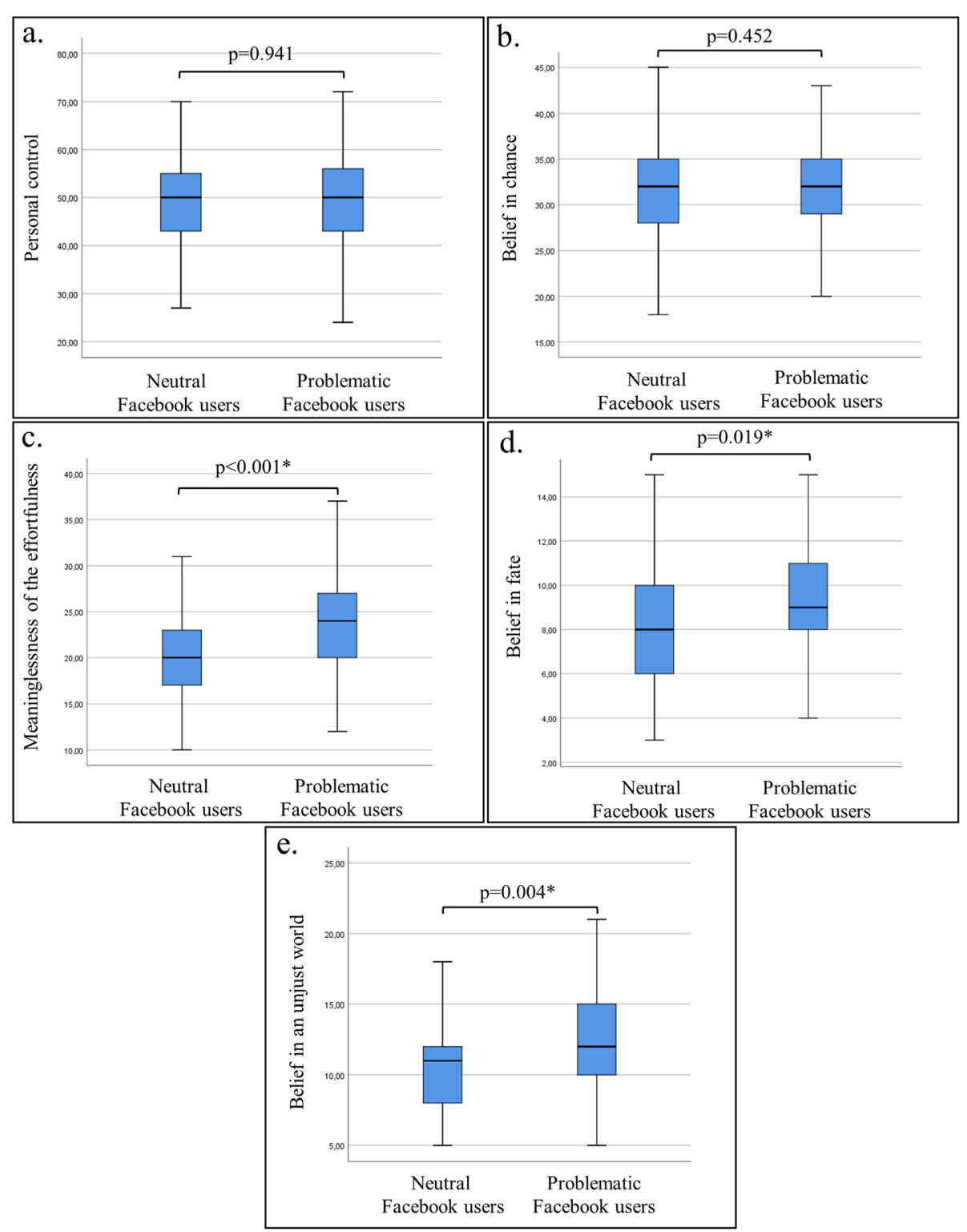

Fig. 1 Comparison of the locus of control domains (a personal control, $\mathbf{b}$ belief in chance, $\mathbf{c}$ meaninglessness of the effortfulness, $\mathbf{d}$ belief in fate, e belief in an unjust world) between neutral vs. problematic Facebook users. Medians are shown by lines in the center of the box-plots; the 25th-75th percentiles are indicated by the boxes and the range by the whiskers

improving students' LOC; thus, they can provide much effective services to their future patients. However, this hypothesis should be proved with the longitudinal studies. In addition, since technology and its innovation are super fast in connecting the life of new generations, but its results in different cultures should be investigated in future studies.

There were several limitations to the present study. Firstly, it had a cross-sectional design; therefore, its results cannot imply causation between problematic Facebook use and LOC. Additionally, Facebook use characteristics could have changed over the years, and the cross-sectional findings cannot be enough to reflect this possibility. Therefore, longitudinal studies are highly warranted. Second, we only investigated Facebook use; however, it is evident that other social media platforms, especially WhatsApp and Instagram, are so frequent. Future studies should investigate their effects on LOC. Lastly, since the study sample was recruited from a single state university, the study's generalizability of findings was limited. Further multicenter studies including students from other private and state universities and different departments would be more informative and representative of the general population. 
Table 3 Correlations between the BFAS and LOC subscale scores in the students with problematic Facebook $(n=267)$

\begin{tabular}{llllll}
\hline & BFAS & $\begin{array}{l}\text { LOC-personal } \\
\text { control }\end{array}$ & $\begin{array}{l}\text { LOC-belief in } \\
\text { chance }\end{array}$ & $\begin{array}{l}\text { LOC-meaninglessness of the } \\
\text { effortfulness }\end{array}$ & $\begin{array}{l}\text { LOC-belief in } \\
\text { fate }\end{array}$ \\
\hline LOC-personal control & $\begin{array}{l}0.16 \\
\left(0.008^{*}\right)\end{array}$ & - & & \\
LOC-belief in chance & $\begin{array}{l}-0.02 \\
(0.811)\end{array}$ & $0.12\left(0.047^{*}\right)$ & - & \\
& $\begin{array}{l}0.31(< \\
\text { LOC-meaninglessness of the }\end{array}$ & $0.03(0.577)$ & $0.38\left(<0.001^{*}\right)$ & - \\
effortfulness & $\begin{array}{l}\left.0.001^{*}\right) \\
\text { LOC-belief in fate }\end{array}$ & $\begin{array}{l}0.05(0.377) \\
0.0 .14\left(0.02^{*}\right)\end{array}$ & $0.16\left(0.009^{*}\right)$ & $0.22\left(<0.001^{*}\right)$ \\
LOC-belief in an unjust world & $\begin{array}{l}0.20 \\
\left(0.001^{*}\right)\end{array}$ & $0.03(0.589)$ & $0.30\left(<0.001^{*}\right)$ & $0.57\left(<0.001^{*}\right)$ & \\
\hline
\end{tabular}

\section{${ }^{*} \mathrm{p}<0.05$}

Values are presented as Spearman's rho $(p)$

$B F A S$, Bergen Facebook Addiction Scale; LOC, locus of control

\section{Conclusion}

Problematic Facebook use was associated with higher external LOC in physiotherapy students. The students having a problematic Facebook use behavior believe meaninglessness of the effortfulness, fate, and an unjust world more than those having a neutral use. The meaninglessness of the effortfulness was the only significant predictor of problematic Facebook use. These negative thoughts might be a problem both for the students themselves and their future patients. The current study's findings indicate an increasing trend for social network use of physiotherapy students who will treat increased psychosocial distress or chronic disability of patients with chronic pain.

\section{Abbreviations}

LOC: Locus of control; BFAS: Bergen Facebook Addiction Scale; IQR: Interquartile range

\section{Acknowledgements}

The authors would like to thank all participants.

\section{Declarations}

\begin{abstract}
Authors' contributions
YS, TK, and BOK conceptualized and designed the study methodologically. YS and BOK collected data. TK and BOK analyzed and interpreted the data. YS, TK, and BOK were major contributors in writing the manuscript. All authors have read and approved the manuscript.
\end{abstract}

\section{Funding}

This research received no specific grant from any funding agency in the public, commercial, or not-for-profit sectors.

\section{Availability of data and materials}

Data will be shared on specific request to the author depending upon the nature and purpose of the requirement.

\section{Ethics approval and consent to participate}

The study was approved by the Noninvasive Research Ethics Board of Dokuz Eylül University (registration number: 2757-GOA, approval number: 2016/16-

15) and performed in accordance with the ethical standards as laid down in the 1964 Declaration of Helsinki (as revised in Brazil 2013). All participants gave written informed consent before entering the study.
Consent for publication

Not applicable

\section{Competing interests}

The authors declare that they have no competing interests.

\section{Author details}

${ }^{1}$ School of Physical Therapy and Rehabilitation, Dokuz Eylül University, Izmir, Turkey. ${ }^{2}$ Department of Physiotherapy and Rehabilitation, Faculty of Health

Sciences, Izmir Katip Celebi University, Izmir, Turkey.

Received: 1 March 2021 Accepted: 26 May 2021

Published online: 11 August 2021

\section{References}

1. Marino C, Gini G, Vieno A, Spada MM. The associations between problematic Facebook use, psychological distress and well-being among adolescents and young adults: a systematic review and meta-analysis. J Affect Disord. 2018;226:274-81. https://doi.org/10.1016/j.jad.2017.10.007.

2. Brailovskaia J, Margraf J. The relationship between burden caused by coronavirus (Covid-19), addictive social media use, sense of control and anxiety. Comput Hum Behav. 2021;119:106720. https://doi.org/10.1016/j. chb.2021.106720.

3. Ong EK, Lim CH, Wong AJ. The role of social media during the COVID-19 pandemic. Ann Acad Med Singap. 2020;49(6):408-10. https://doi.org/10.471 02/Annals-acadmedsg.202080.

4. Aker S, Mıdık Ö. The views of medical faculty students in Turkey concerning the COVID-19 pandemic. J Community Health. 2020;45(4):684-8. https://doi. org/10.1007/s10900-020-00841-9.

5. Karadağ E, Yücel C. Distance education at universities during the novel coronavirus pandemic: an analysis of undergraduate students' perceptions. Yuksekogretim Dergisi. 2020;10(2):181-92 Article in Turkish.

6. Athukorala A. Factors affecting use of social media by university students: a study at Wuhan University of China. J Univ Librarians Assoc Sri Lanka. 2018; 21(2).

7. Rotter JB. Generalized expectancies for internal versus external control of reinforcement. Psychol Monogr. 1966;80(1):1-28. https://doi.org/10.1037/ h0092976.

8. Yeşilyaprak B. Eğitimde bireysel farklılıklar [Individual differences in education]. In: Deryakulu K-D, editor. Denetim odağı [Locus of control]. Ankara: Nobel Yayınevi; 2004. Book in Turkish.

9. Arslan C, DilmaÇ B, Hamarta E. Coping with stress and trait anxiety in terms of locus of control: a study with turkish university students. Soc Behav Pers. 2009;37(6):791-800. https://doi.org/10.2224/sbp.2009.37.6.791.

10. Hou J, Ndasauka $Y$, Jiang $Y$, Ye Z, Wang $Y$, Yang $L$, et al. Excessive use of WeChat, social interaction and locus of control among college students in China. PLoS One. 2017;12(8):e0183633-e.

11. Ye $Y$, Lin L. Examining relations between locus of control, loneliness, subjective well-being, and preference for online social interaction. Psychol Rep. 2015;116(1):164-75. https://doi.org/10.2466/07.09.PR0.116k14w3. 
12. Beinart NA, Goodchild CE, Weinman JA, Ayis S, Godfrey EL. Individual and intervention-related factors associated with adherence to home exercise in chronic low back pain: a systematic review. Spine J. 2013;13(12):1940-50. https://doi.org/10.1016/j.spinee.2013.08.027.

13. Oliveira VC, Ferreira PH, Ferreira ML, Tibúrcio L, Pinto RZ, Oliveira W, et al. People with low back pain who have externalised beliefs need to see greater improvements in symptoms to consider exercises worthwhile: an observational study. Aust J Physiother. 2009;55(4):271-5. https://doi.org/10.1 016/S0004-9514(09)70007-8.

14. Sengul YS, Algun C, Arda MN, Ozer E, Angin S. Health locus of control beliefs and postural control in chronic low back pain patients. J Neurol Sci (Turkish). 2011;28(2):222-35.

15. Sengul Y, Kara B, Arda MN. The Relationship between health locus of control and quality of life in patients with chronic low back pain. Turk Neurosurg. 2010;20(2):180-5. https://doi.org/10.5137/1019-5149.JTN.261609.1.

16. Goesling J, Lin LA, Clauw DJ. Psychiatry and pain management: at the intersection of chronic pain and mental health. Curr Psychiatry Rep. 2018; 20(2):12. https://doi.org/10.1007/s11920-018-0872-4.

17. Nielsen M, Keefe FJ, Bennell K, Jull GA. Physical therapist-delivered cognitive-behavioral therapy: a qualitative study of physical therapists' perceptions and experiences. Phys Ther. 2014;94(2):197-209. https://doi. org/10.2522/ptj.20130047.

18. Overmeer T, Boersma K, Denison E, Linton SJ. Does teaching physical therapists to deliver a biopsychosocial treatment program result in better patient outcomes? A randomized controlled trial. Phys Ther. 2011;91(5):80419. https://doi.org/10.2522/ptj.20100079.

19. O'Keeffe M, O'Sullivan PB, O'Sullivan K. Education can 'change the world': can clinical education change the trajectory of individuals with back pain? 2019:bjsports-2018-100190.

20. Chak K, Leung L. Shyness and locus of control as predictors of internet addiction and internet use. CyberPsychol Behav. 2004;7(5):559-70. https:// doi.org/10.1089/cpb.2004.7.559.

21. Dağ I. Locus of control scale: scale development, reliability and validity study [Kontrol odağı ölçeği (KOÖ): ölçek geliştirme, güvenirlik ve geçerlik çalışması]. Türk Psikoloji Dergisi. 2002;17(49):77-90 Article in Turkish.

22. Andreassen CS, Torsheim T, Brunborg GS, Pallesen S. Development of a Facebook addiction scale. Psychol Rep. 2012;110(2):501-17. https://doi.org/1 0.2466/02.09.18.PR0.110.2.501-517.

23. Türkyılmaz M. The translation of facebook addiction scale into Turkish and impact of facebook addiction to reading ability [Facebook Bağımlılı̆̆ı Ölçeğinin Türkçeleştirilmesi ve Facebook Bağımlılığının Okuma Becerisine Etkisi]. Int J Soc Sci. 2015;36(Summer II):265-80 Article in Turkish.

24. Gedam SR, Shivji IA, Goyal A, Modi L, Ghosh S. Comparison of internet addiction, pattern and psychopathology between medical and dental students. Asian J Psychiatr. 2016;22:105-10. https://doi.org/10.1016/j.ajp.201 6.06.007.

25. Gonzalez MR, Gasco J, Llopis J. Facebook and academic performance: a positive outcome. Anthropologist. 2016;23(1-2):59-67. https://doi.org/10.1 080/09720073.2016.11891924.

26. Ratanpara V, Dave D. Prevalence of internet addiction among undergraduate university physiotherapy students and correlation with academic performance, depression and general health. Physiotherapy. 2015; 101:e1261-e2. https://doi.org/10.1016/j.physio.2015.03.1168.

27. Sharma A, Sahu R, Kasar PK, Sharma R. Internet addiction among professional courses students: a study from central India. Int J Med Sc Public Health. 2014;3(9):1069-73. https://doi.org/10.5455/ijmsph.2014.18062 0142.

28. Firat M. Relationship between self-control and Facebook use: case of CEIT students. Educ Sci Theory Pract. 2017;17(4):1179-201.

29. Dieter J, Hoffmann S, Mier D, Reinhard I, Beutel M, Vollstadt-Klein S, et al. The role of emotional inhibitory control in specific internet addiction - an fMRI study. Behav Brain Res. 2017;324:1-14. https://doi.org/10.1016/j.bbr.201 7.01.046.

30. Bandura A, Locke EA. Negative self-efficacy and goal effects revisited. J Appl Psychol. 2003:88(1):87-99. https://doi.org/10.1037/0021-9010.88.1.87.

31. Richardson M, Abraham C, Bond R. Psychological correlates of university students' academic performance: a systematic review and meta-analysis. Psychol Bull. 2012;138(2):353-87. https://doi.org/10.1037/a0026838.
32. Au EW. Locus of control, self-efficacy, and the mediating effect of outcome control: predicting course-level and global outcomes in an academic context. Anxiety Stress Coping. 2015;28(4):425-44. https://doi.org/10.1080/1 0615806.2014 .976761$.

33. Iskender M, Akin A. Social self-efficacy, academic locus of control, and internet addiction. Comput Educ. 2010;54(4):1101-6. https://doi.org/10.1016/ j.compedu.2009.10.014.

\section{Publisher's Note}

Springer Nature remains neutral with regard to jurisdictional claims in published maps and institutional affiliations.

\section{Submit your manuscript to a SpringerOpen ${ }^{\circ}$ journal and benefit from:}

- Convenient online submission

- Rigorous peer review

- Open access: articles freely available online

High visibility within the field

- Retaining the copyright to your article

Submit your next manuscript at $\boldsymbol{\nabla}$ springeropen.com 